\title{
Influence of Tunneling Incentive, Risk Management and Company Characteristics on Tax Avoidance with Corporate Social Responsibility Disclosure Asa Moderating Variable In Mining Companies Listed on IDX
}

\author{
Suripto $^{1 *}$, Novitaria ${ }^{2}$ \\ 1,2 Pamulang University, Indonesia
}

\section{ART ICLE I N F O}

\section{Article history:}

Received July 11,2021

Revised July 12, 2021

Accepted October 14, 2021

Available online November 25, 2021

\section{Keywords:}

Tax Avoidance, Tunneling Incentive, Risk Management, Leverage

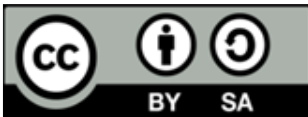

This is an open access article under the CC BY-SA license.

Copyright $(2021$ by Author. Published by Universitas Pendidikan Ganesha.

\begin{abstract}
A B S T R A C T
In Indonesia, there are tax evasion cases involving taxpayers paying taxes that must be paid in various ways. This gap phenomenon occurs in the case of a coal mining company that has been proven to have evaded tax. In addition, there are many more cases that show corporate tax evasion and have caused many state losses that impact the country's economic growth because of their efforts to reduce costs which are a source of income for the state. This study aims to provide empirical evidence of the effect of applying tunneling incentives, risk management, and firm characteristics using the leverage ratio and firm size, as independent variables, on tax avoidance as the dependent variable, with the use of Corporate Social Responsibility (CSR) as the independent variable. Variable moderator. Determination of the sample using the purposive sampling technique obtained a sample of 8 companies with 40 observational data. The analysis technique and hypothesis testing were carried out by panel data regression analysis through Eviews-11. The results showed that tunneling incentive and firm size had a significant positive effect on tax avoidance. Risk management and leverage do not affect tax avoidance. Corporate social responsibility can only moderate the effect of tunneling incentives on tax avoidance and firm size on tax avoidance but cannot moderate the effect of risk management and leverage.
\end{abstract}

\section{INTRODUCTION}

Taxes are one of the biggest contributors to a country's income (Alstadsæter et al., 2022; Uemura, 2022). This can be seen in the growth of tax revenue in 2019 of 1,545.3 Trillion Rupiah's, compared to nontax state revenue in the same year, which was only 405 Trillion Rupiah (Damayanti \& Wulandari, 2021). There are cases in Indonesia regarding tax avoidance involving corporate taxpayers with the aim of minimizing the tax burden that must be paid through various means (Benkraiem et al., 2022; Hajawiyah et al., 2021). In this study, there is a gap phenomenon in the tax avoidance variable. This gap phenomenon occurs in the case of coal mining companies which proven to have committed tax avoidance. Data from the finance ministry shows that the tax ratio contributed by the mineral and coal mining sector in 2016 was only $3.9 \%$, while the national tax ratio in 2016 was $10.4 \%$. The low tax ratio cannot be separated from the problem of tax avoidance by coal industryparties. The Ministry of Finance noted that more taxpayers holding mineral and coal mining business permits did not report their annual tax returns than those who did. In 2015 out of 8,003 coal industry taxpayers, there were 4,532 taxpayers who did not report their tax returns. This figure certainly does not include small-scale coal company who are not registered as taxpayers.

In addition to the cases above, there are many more cases that demonstrate corporate tax avoidance and have caused many losses to the state which have an impact on the country's economic growth because of their efforts to reduce tax costs which are a source of income for the state (Benkraiem et al., 2022; Hajawiyah et al., 2021; Hasan et al., 2022). In addition to the Gap Phenomenon, this study also found a research gap on the effect of tunneling incentives on tax avoidance. The research gap in this study occurred in research conducted that the tunneling incentive variable has a positive and significant effect on tax avoidance (Lestari \& Solikhah, 2019; Rifan, 2019). Based on the test results, it is known that the tunneling 
incentive variable has no significant effect on tax avoidance (T. Y. H. Tang, 2016). In this variable, there is also a research gap regarding the characteristics of the company. Company characteristics affect tax avoidance. The variable of company characteristics has no effect on tax avoidance (Mahanani et al., 2017; Rani et al., 2018).

Tax avoidance is the process of controlling actions in order to avoid the consequences of imposing taxes that are not desired but are still within the framework of tax regulations (Alstadsæter et al., 2022; Chen et al., 2022; T. Tang et al., 2022). Payment of income tax to companies is the transfer or transfer of wealth from the company to the government, the tax burden paid is a large cost for the company, therefore the companies will tend to avoid taxes in an effort to be able to pay as efficiently as possible (Benkraiem et al., 2022; Campa et al., 2021; Shams et al., 2022). Taxpayers always want small tax payments, which is why not a few taxpayers do tax avoidance both legally and illegally (Han et al., 2021; Sugiyanto et al., 2020). From this understanding, it can be seen that corporate planning by doing tax avoidance is the only legal way that can be taken by taxpayers in order to pay their tax payments efficiently. Previous research stated that Corporate Social Responsibility (CSR) has an effect on tax avoidance, while (Fadrianto \& Mulyani, 2018; Mahanani et al., 2017; Wardani \& Purwaningrum, 2018). Based on the explanation above, the purpose of this research is to examine on tax avoidance Tunnelling Incentive, Risk Management, Company Characteristics on Tax Avoidance with Corporate Social Responsibility Disclosureas a moderating variable interesting and important for research. Tunneling incentives can reduce the tax burden and increase posttax profit for the year.

Tunneling Incentive is a behavior of the majority shareholder who transfers the company's assets and profits for their own benefit, but the minority shareholder will be charged as a fee holder (Aharony et al., 2010; Darma, 2020; Pratiwi, 2018). Agency theory considers that the company's management as an agent will take advantage of the existence of tax incentives in the form of tunneling incentives. The results show that tunneling can be an incentive for tax avoidance (Lee \& Bose, 2021; T. Y. H. Tang, 2016). From the explanation above, it can be concluded that tunneling incentive is the transfer of resources in the form of assets, profit sharing, granting special rights granted to the majority shareholder (principal) and harming the minority shareholder (agent). Risk Management is a complex process that includes identifying, managing and minimizing business risks, both financial and operational risks of the company (Najafi-Tavani et al., 2022; Popp et al., 2021). Risk management is a structured approach to managing uncertainty related to threats, a series of human activities including, risk assessment, developing strategies to manage them and mitigating risks using empowerment or resource management (Varga et al., 2021; Yang et al., 2019). Based on the understanding above, risk management is a structured approach or methodology in managing uncertainty related to threats including identifying, managing and minimizing business risks, both financial and operational risks of the company so as to enable companies to be more careful and productive to avoid things that are not useful because get rid of unnecessary resources and prevent harm.

The CSR concept places the practice of social responsibility as a tool to "bribe" the community so that its business practices can be accepted by vulnerable groups who are disadvantaged and become victims of the company's business activities. In other words, the company carries out CSR activities as one of its public relations strategies. Companies that carry out CSR as mere philanthropy do not consider the integration between giving charity to the community and achieving the company's mission to uphold the values and goals of the company. Based on this phenomenon, it is not surprising that CSR is seen as an additional cost for companies and it is difficult to make their business more profitable and sustain. This study aims to provide empirical evidence of the effect of applying tunneling incentives, risk management and company characteristics using the leverage ratio and firm size variables, as independent variables, on tax avoidance as the dependent variable, with Corporate Social Responsibility (CSR) disclosure as the moderating variable.

\section{METHODS}

This research is classified into quantitative research using secondary data as a source of research data. The population of this research is 45 mining companies listed on the Indonesia Stock Exchange in 2016-2019. Determination of the sample using purposive sampling technique, obtained a sample of 8 companies with 40 observation data for 5 years in Table 1.

The data collection technique used in this study is the documentation technique on secondary data. The data used is in the form of annual reports of mining companies listed on the IDX during 2016-2019. The data analysis technique used consisted of descriptive statistics, panel data regression model selection, classical assumption testing (normality, multicollinearity, heteroscedasticity, autocorrelation), panel data regression analysis, and hypothesis testing. This study uses five research variables consisting of one dependent variable and 3 independent variables and one moderating variable. Tax avoidance in this study 
was measured using the ratio of effective tax rates (ETR)(Suripto \& Sugiyanto, 2020). Effective Tax Rates (ETR) in this study only uses the main model used, namely the income tax burden divided by the company's pre-tax income. Conceptually, tunneling incentive is proxied by the percentage of share ownership above $20 \%$ as controlling shareholder by a foreign company. The criteria for a concentrated ownership structure are based on the Capital Market Law no. IX.H.1, which explains that the controlling shareholder is a party who owns $20 \%$ or more equity shares or securities (Hartati et al., 2015). PSAK No. 15 also states about the significant influence held by shareholders with a percentage of $20 \%$ or more. The measurement used for Tunneling Incentive as an independent variable.

Table 1. Sample Criteria

\begin{tabular}{|c|c|c|c|}
\hline No & Sample Criteria & $\begin{array}{c}\text { Criteria } \\
\text { Violation }\end{array}$ & $\begin{array}{l}\text { Meet the } \\
\text { criteria }\end{array}$ \\
\hline 1 & $\begin{array}{l}\text { Mining sector companies listed on the Indonesia Stock Exchange } \\
\text { in 2015-2019 }\end{array}$ & & 45 \\
\hline 2 & $\begin{array}{l}\text { Mining sector companies that publish financial reports for the } \\
\text { period 2015-2019 }\end{array}$ & -7 & 38 \\
\hline \multirow[t]{4}{*}{3} & $\begin{array}{l}\text { Mining sector companies that publish Sustainability Reports } \\
\text { with Core Option during the } 2015-2019 \text { period }\end{array}$ & -30 & 8 \\
\hline & Total Sample & & 8 Companies \\
\hline & Total x Years of Observation & & $8 \times 5=40$ \\
\hline & Number of Samples After Outlier & & 40 \\
\hline
\end{tabular}

In this study, Leverage is measured using the Debt-to-Equity Ratio (DER), which is a ratio that measures total liabilities to equity (Shareholders' Equity). Leverage describes the proportion of long-term debt to total assets owned by the company. This can be used to find out the funding decisions made by the company. Corporate Social Responsibilityis a business commitment to act ethically, contribute to economic development, improve the quality of life of workers, local communities, and large of society. The Corporate Social Responsibility variable in this study was measured by analysis content. Analysis content is a method or technique used to transfer qualitative data into quantitative data through codification. Thus, this research was conducted by transferring qualitative information about the company's CSR disclosures contained in the company's annual report into a score. This score is assigned to CSR disclosures that comply with the statement guidelines (disclosure items) Global Reporting Initiative Index (GRI) Standards.

\section{RESULTS AND DISCUSSIONS}

\section{Results}

Descriptive statistical analysis is explained through the minimum value, maximum value, mean, and standard deviation values. The results of descriptive statistical analysis in this study indicate that the average company performs tax evasion by 33\%. The minimum value of $7 \%$ is at PT. Indika Energi Tbk and a maximum value of $90 \%$ at PT. Indika Energi Tbk.

Table 2. Descriptive statistics

\begin{tabular}{lcccccc}
\hline & ETR & TUN & RMC & DER & SIZE & CSR \\
\hline Mean & 0.333350 & 0.617325 & 0.875000 & 30,81715 & 0.444475 & 316,0500 \\
Median & 0.292500 & 0.650000 & 1.0000000 & 30.86100 & 0.429500 & 292.5000 \\
Maximum & 0.908000 & 0.698000 & 1.0000000 & 32.37600 & 0.742000 & 5830000 \\
Minimum & 0.072000 & 0.378000 & 0.000000 & 29.33600 & 0.126000 & 125.0000 \\
Std. Dev. & 0.202501 & 0.078959 & 0.334932 & 0.792486 & 0.169701 & 133.2287 \\
Skewness & 1.028177 & -2.025851 & -2.267787 & 0.125068 & -0.139804 & 0.604347 \\
Kurtosis & 3.444589 & 6.839259 & 6.142857 & 2.682569 & 2.043468 & 2.355212 \\
Jarque-Bera & 7.377082 & 51.92701 & 50.74830 & 0.272217 & 1.655224 & 3.127824 \\
Probability & 0.025008 & 0.000000 & 0.000000 & 0.872748 & 0.437092 & 0.209316 \\
Sum & 13.33400 & 24.69300 & 35000000 & 1232.686 & 17.77900 & 12642.00 \\
Sum Sq. Dev. & 1.599257 & 0.243147 & 4.375000 & 24.49331 & 1.123138 & 692245.9 \\
\hline Observations & $\mathbf{4 0}$ & $\mathbf{4 0}$ & $\mathbf{4 0}$ & $\mathbf{4 0}$ & $\mathbf{4 0}$ & $\mathbf{4 0}$ \\
\hline
\end{tabular}

There are three panel data regression models that can be used to perform panel data regression analysis, namely the common effect model (CEM), the fixed effect model (FEM), and the random effect model 
(REM). The best model selection method that can be used in panel data regression analysis is obtained by performing three tests, namely the Chow test, Hausman test, and the Lagrange multiplier test. The results of the panel data regression model selection in this study, namely the Chow test, showed a chi-square cross section probability value of $0.0425<0.05$. Hausman test shows the probability value of chi-squares is 1.0000 $>0.05$. The LM test shows the value of both is $0.0161<0.05$. So it can be concluded that the random effect model is the right model to be used as a panel data regression model. Normality test is carried out to detect whether the residual has a normal distribution or not. The most widely used residual normality test is the Jarque-Bera or JB test (Ghozali, 2017). Jarque-Bera test decision making is done if theJarque-Bera probability value $>$ significance level $(\alpha=0.05)$, then it does not reject H0 or the residual has a normal distribution. The following are the results of the Jarque-Bera test in Figure 1.

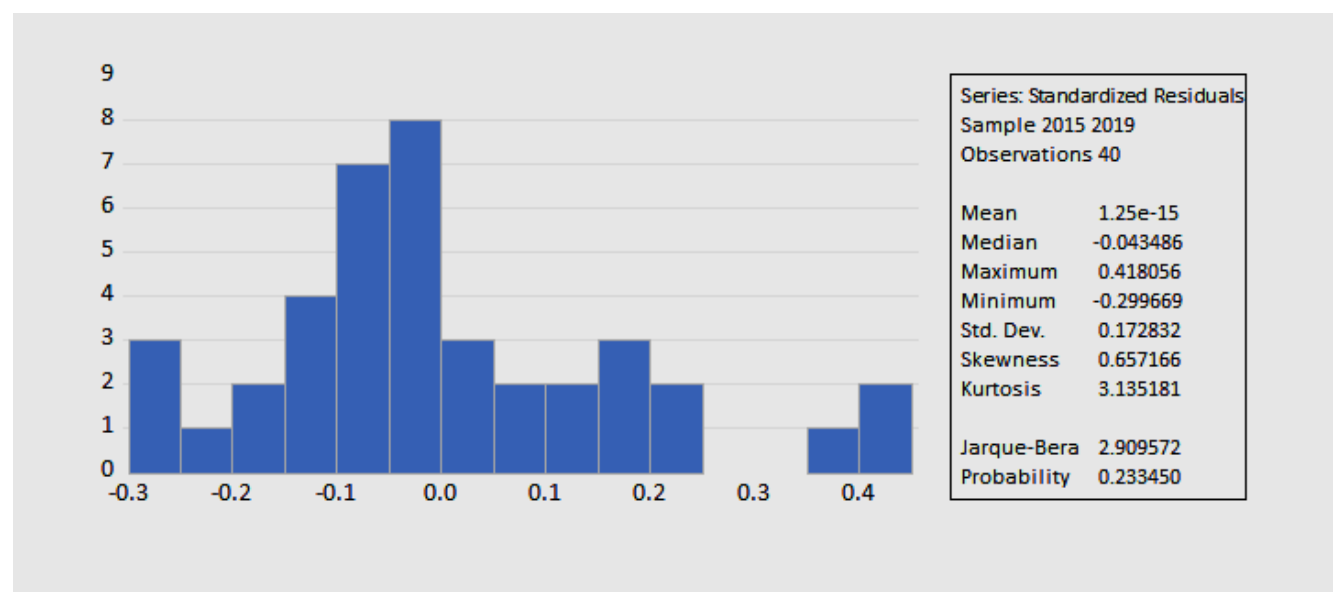

Figure 1. Jarque-Bera test result

From the figures abovenormality testing with the help of Eviews-11 produces a Jarque-Bera value of 2.909572 and a probability value of 0.233450 which is greater than a significance level of 0.05 . Because the probability value and the Jarque-Bera value $>$ the significance level $(\alpha=0.05)$, it does not reject H0 or the residual has a normal distribution, so it can be said that the normality requirements can be met. To find out the multicollinearity in a model is to look at the correlation coefficient. Multicollinearity occurs if the correlation of each independent variable is $>0.90$, while if the correlation value of each independent variable is $<0.90$ then the regression model does not have a multicollinearity problem (Ghozali, 2017).

Table 3. Multicollinearity Test Results

\begin{tabular}{cccccc}
\hline & X1 & X2 & X3A & X3B & Z \\
\hline TUN & 1.0000000 & -0.158403 & -0.644247 & -0.242544 & 0.062373 \\
RMC & -0.158403 & 1.0000000 & 0.312484 & -0.196069 & -0.254413 \\
DER & -0.644247 & 0.312484 & 1.0000000 & 0.013089 & 0.416858 \\
SIZE & -0.242544 & -0.196069 & 0.013089 & 1.0000000 & -0.038749 \\
CSR & 0.062373 & -0.254413 & 0.416858 & -0.038749 & 1.0000000 \\
\hline
\end{tabular}

Based on the Table 3 of test results on the value of the correlation coefficient above, each independent variable does not have a correlation greater than 0.90 , so it can be concluded that the model does not experience multicollinearity problems. Based on the selection of the regression model previously carried out, the random effect model was the most appropriate regression model to be used in this study. The adjusted R-squared value of 0.254646 shows the ability of the independent variables used in this study, namely tunneling incentives, risk management and company characteristics as well as moderating variables, namely Corporate Social Responsibility (CSR) in explaining the dependent variable, namely avoidance tax of $25.4 \%$, the remaining $74.6 \%$ is explained by other variables that are not used in this study.

Based on the panel data regression analysis test, it was obtained that $\mathrm{df} 1=\mathrm{k}$ (the number of independent variables plus the dependent variable) -1 , namely $4-1=3$. While df $2=n$ (amount of data) $-\mathrm{k}$ (the number of independent variables plus the dependent variable) which is $40-4=36$, with alpha $(\alpha)=$ 0.05 so that the F-table value is 2.87. It is known that the result of the F-count simultaneously is 3.250489 so that the F-count is greater than the F-table $(3.250489>2.87)$ or rejects $\mathrm{H} 0$ and accepts Ha1. While the probability value is smaller than the 0.05 significance level $(0.00000<0.05)$ or rejecting $\mathrm{H} 0$ and accepting Ha1. So it can be concluded that the independent variables (tunneling incentive, risk management as and 
company characteristics as) in this study simultaneously have a positive and significant effect on the dependent variable (tax avoidance). The t-test in this study was carried out with the help of Eviews-11 to analyze panel data regression using a random effect model. The t-test decision making is done by looking at the t-table value, to obtain the t-table value, it is necessary to find df (degree of freedom) with the formula $\mathrm{df}=\mathrm{n}$ (amount of observation data) - $\mathrm{k}$ (number of independent variables plus dependent variable). So in this study obtained df $=40-4=36$ and a significance level of 0.05, so that the t-table is 2.02809 (two-way test).

\section{Discussion}

These results are in line with research conducted, states that tunnelling can be an incentive for tax avoidance (Tang, 2016). One form of such action is to carry out transactions with related parties to transfer assets or profits to leave the company through unreasonable pricing for the interests of the majority shareholders and minority shareholders also bear the costs of these costs (Putri, 2017; Sadewo \& Hartiyah, 2017). Purchase of goods or services above fair value and sales of goods or services below fair price. One form of such action is to carry out transactions with related parties to transfer assets or profits to leave the company through unreasonable pricing for the interests of the majority shareholders and minority shareholders also bear the costs of these costs. Based on agency theory, agency conflicts can occur between the majority shareholder and the minority shareholder. This conflict can occur because the majority shareholder imposes all his wishes on the manager for the personal interest of the majority shareholder. Therefore, companies can easily take negative actions such as tax evasion. Efforts are made such as moving assets or profits owned by the company, so that the profits generated by the company are lower. The process of transferring assets or the resulting profit will reduce the profits to be obtained by the minority shareholders, the impact is that the minority shareholders experience a decrease in the welfare provided by the company. The practice of transferring assets or profits by managers due to encouragement from the majority shareholder is one of the main triggers for transfer pricing. The tunneling incentive action through the transfer effort will encourage the majority shareholder to get more profit so that the majority shareholder takes transfer pricing action (Rifan, 2019; T. Y. H. Tang, 2016). The practices of tunneling incentives include not distributing dividends, selling company assets to majority shareholders or companies controlled by majority shareholders at a lower price than the price they should be, the company's key positions are occupied by majority shareholders, so that the tunneling process can be carried out more easily.

If the shareholders have great control in a company, then the company's actions to conduct transactions with related parties can be used to transfer the company's assets and profits out of the company through unfair pricing for the benefit of the majority shareholder rather than distributing dividends to minority shareholders (Kovermann \& Velte, 2019; T. Y. H. Tang, 2016). This results in losses for minority shareholders because they have to bear the costs charged by the majority shareholders for the benefit of the majority shareholders only. This effort is done only because of the motive to do tax avoidance. Tax avoidance practices are often carried out by multinational companies who want high profits. The decision taken to avoid tax is influenced by non-tax factors as well, namely the bonus mechanism (Portillo \& Block, 2012; Rosid et al., 2018). Purchase of goods or services above fair value and sales of goods or services below fair price. Performance measurement indicators can be seen from optimal profit, for this reason, efforts are made to reduce the tax burden as low as possible in a way that is classified as legal, namely tax avoidance. The results of this study were strengthened through research, namely risk management has no effect on tax avoidance (Fadrianto \& Mulyani, 2018; Mahanani et al., 2017).

Risk management is related to decision making that contributes to the achievement of organizational goals by applying it at the individual and functional activity levels (Fadrianto \& Mulyani, 2018; Rustinsyah et al., 2021). The desire to contribute large profits to stakeholders is faced with the tax burden as a profit deduction, so it is not uncommon for companies to carry out tax avoidance and tax evasion in order to minimize the tax liability as an act of tax management. This of course has the potential to worsen the company's image in the eyes of stakeholders. On the other hand, the direct effect of tax avoidance can increase cash flow through tax savings but is also associated with high agency costs. On the other hand, the indirect effect of changes in tax avoidance aggressiveness is that it will complicate business transactions, lack of transparency of information, and low company value. A good risk management system allows the company to evaluate and control the company's risks, while not getting involved in scandals, both small and large, especially those that have the potential to bring down the company, such as those experienced by Enron Corporation and Worldcom. The existence of institutional owners plays an active role in overseeing the effectiveness and efficiency of the company's management so that it can hinder the opportunistic behavior of managers. The existence of institutional owners indicates that there is pressure from institutional parties on company management to carry out aggressive tax policies in order to obtain 
maximum profits for institutional owners. Institutional owners expect companies to contribute to development in the form of tax payments. The existence of institutional owners in the corporate governance mechanism serves as an obstacle to tax avoidance decisions (Luthan et al., 2016; Puspitaningrum \& Atmini, 2012).

Based on agency theory, an efficient contract in an agency relationship cannot occur if the interests of the principal and agent are in conflict. Supervision from outside the company is needed to supervise the agent. This supervision can affect the attitude of company agents, because the more supervision in the company, the agents will be more careful for every decision that will be made. However, the existence of long-term debt or leverage on the company will cause a fixed burden, namely the interest that must be paid. In the tax regulations Article 6 paragraph 1 letter number 3 of Law number 36 of 2008 concerning Income Tax, loan interest is a deductible expense against taxable income so that it will result in a reduced taxable profit of the company. Reduced taxable profit will ultimately reduce the amount of tax that must be paid by the company. The results of hypothesis testing state that Leverage has no effect on tax avoidance, meaning that the high and low leverage will not affect the company to do tax avoidance, this happens because the higher the debt level of a company, the management will be more conservative in conducting financial reporting or company operations. This shows that the greater the value of the company's debt, the lower the tax avoidance practice carried out by the company. One of the funding policies is with debt or leverage is the level of debt used by the company in financing. Companies that use debt in the composition of financing, there will be an interest expense that must be paid. The higher the value of the leverage ratio, the higher the amount of funding from third party debt used by the company and the higher the interest costs arising from the debt. The results of this study are in line with research conducted showed that leverage had no effect on tax avoidance (Alstadsæter et al., 2022; Damayanti \& Wulandari, 2021).

Based on the results of the regression analysis of the firm size panel data, the significance value is $0.0269<0.05$ and the $t$-count value for the firm size variable is $2.570184>$ the $t$-table value is 2.02809 , so it can be concluded that in the partial t-test above, $\mathrm{H}_{\mathrm{a}}$ rejected and $\mathrm{H}_{3 \mathrm{~b}}$ accepted, which means that the variable company size partially has a significant positive effect on tax avoidance. This reflects that the larger the company, the lower its CETR will be. This means that the company's ability to avoid tax is getting bigger, because the ability to hire people who are experts in the field of taxation or hire tax consultants is getting bigger which can increase tax avoidance by the company. Based on the results of the panel data regression analysis test, the multiplication between tunneling incentive and CSR has a t-count of 2.925966 with a significance value of 0.0019 . H accepted, because the significance value is less than $0.05(0.0019<0.05)$. In multinational companies, the majority shareholder and company management can take actions that can be detrimental to the government and minority shareholders. One form of such action is to carry out transactions with related parties to transfer assets or profits to leave the company through unreasonable pricing for the interests of the majority shareholders and minority shareholders also bear the costs of these costs.

The results of this study are not in line with research conducted by (Dewi Yanti, 2018; Fadrianto \& Mulyani, 2018; Mahanani et al., 2017).Based on the results of the panel data regression analysis, the multiplication between risk management and CSR has a t-count of 1.713231 with a significance value of 0.0612 . Then $H_{6}$ rejected, because the significance value is greater than $0.05(0.0612>0.05)$. So that CSR is not able to moderate the relationship between risk management and tax avoidance. The risk control function through the presence of a risk management committee as a separate part of the audit committee provides a more focused and optimal management, implementation, and assessment of risk. The existence of a risk management committee that has experience and expertise in managing risk is very beneficial for the board of commissioners. The risk management committee is tasked with providing input and evaluation to the board of commissioners regarding the risk management system, internal control, and information on how to mitigate company risk.

This research shows the results that Corporate Social Responsibility has a negative effect on the relationship between Leverage and Tax Avoidance (Fadrianto \& Mulyani, 2018). Based on the results of the panel data regression analysis, the multiplication between leverage and CSR has a t-count of 0.178210 with a significance value of 0.8598 . Then $\mathrm{H7}$ a rejected, because the significance value is greater than $0.05(0.8598$ $>0.05$ ). So that CSR is not able to moderate the relationship between leverage and tax avoidance. This shows that the higher or lower the debt level of a company, it will not affect the tax avoidance practices carried out by the company. The existence of CSR disclosure in the financial statements is expected to be a plus for the company to increase investor confidence. Based on the table of moderated regression analysis (MRA) test results, the multiplication between company size and CSR has a t-count of 2.256147 with a significance value of 0.0315 . Then $\mathrm{H} 7 \mathrm{a}$ accepted, because the significance value is less than $0.05(0.0315<0.05)$. So that CSR can moderate the relationship between company size and tax avoidance. This reflects that the larger the company, the lower its CETR will be. This means that the company's ability to avoid tax is getting bigger, 
because the ability to hire people who are experts in the field of taxation or hire tax consultants is getting bigger which can increase tax avoidance by the company. However, when there are other factors such as CSR, it is suspected that it will weaken the relationship between the two, because CSR will strengthen the value of the Effective Tax Rate, which means the company will be more transparent in building good relations with stakeholders and the community.

\section{CONCLUSION}

The partial test results show that the tunneling incentive variable has a significant effect on tax avoidance in mining companies listed on the Indonesia Stock Exchange for the 2015-2019 period. Second, the partial test results show that the risk management variable has no effect on tax avoidance in mining companies listed on the Indonesia Stock Exchange for the 2015-2019 period. And third, the partial test results show that the variable characteristics of the company proxies with leverage have no significant effect on tax avoidance in mining companies listed on the Indonesia Stock Exchange for the 2015-2019 period. The company's characteristic variable which is proxied by company size has a significant effect on tax avoidance in mining companies listed on the Indonesia Stock Exchange for the 2015-2019 period. Fifth, Simultaneous test results show that the variables of tunneling incentive, risk management and company characteristics have a simultaneous and significant effect on tax avoidance in mining companies listed on the Indonesia Stock Exchange for the 2015-2019 period. Sixth, the results of this test indicate that the Corporate Social Responsibility (CSR) variable is able to moderate and strengthen the tunneling incentive relationship to tax avoidance in mining companies listed on the Indonesia Stock Exchange for the 20152019 period. Seventh, the results of this test indicate that the Corporate Social Responsibility (CSR) variable is not able to moderate risk management on tax avoidance in mining companies listed on the Indonesia Stock Exchange for the 2015-2019 period. Eighth, the results of this test indicate that the Corporate Social Responsibility (CSR) variable is not able to moderate leverage on tax avoidance in mining companies listed on the Indonesia Stock Exchange for the 2015-2019 period.

\section{REFERENCES}

Aharony, J., Wang, J., \& Yuan, H. (2010). Tunneling as an incentive for earnings management during the IPO process in China. Journal of Accounting and Public Policy, 29(1). https://doi.org/10.1016/j.jaccpubpol.2009.10.003.

Alstadsæter, A., Johannesen, N., Herry, S. L. G., \& Zucman, G. (2022). Tax evasion and tax avoidance. Journal of Public Economics, 206. https://doi.org/10.1016/j.jpubeco.2021.104587.

Benkraiem, R., Gaaya, S., \& Lakhal, F. (2022). Corporate tax avoidance, economic policy uncertainty, and the value of excess cash: International evidence. Economic Modelling, 108. https://doi.org/10.1016/j.econmod.2021.105738.

Campa, D., Ginesti, G., Allini, A., \& Casciello, R. (2021). Chief financial officer co-option and tax avoidance in European listed firms Author links open overlay panelDomenicoCampaaGianlucaGinestibAlessandraAllinibRaffaelaCa. Journal of Accounting and Public Policy. https://doi.org/10.1016/j.jaccpubpol.2021.106935.

Chen, H., Liu, S., Wang, J., \& Wu, Z. (2022). The effect of geographic proximity on corporate tax avoidance: Evidence from China. Journal of Corporate Finance, 72. https://doi.org/10.1016/j.jcorpfin.2021.102131.

Damayanti, V. N., \& Wulandari, S. (2021). The Effect Of Leverage, Institutional Ownership, And Business Strategy On Tax Avoidance (Case Of Listed Manufacturing Companies In The Consumption Goods Industry Period 2014-2019). Jurnal Accountability, 10(1). https://doi.org/10.32400/ja.33956.10.1.2021.16-26.

Darma, S. S. (2020). Pengaruh Pajak, Exchange Rate, Tunneling Incentive Dan Bonus Plan Terhadap Transaksi Transfer Pricing Pada Perusahaan Multinasional Studi Empiris Pada Perusahaan Manufaktur Yang Terdaftar Di Bei Tahun 2014-2017. Urnal Ekonomi Efektif, 2(3). https://doi.org/10.32493/JEE.v2i3.6811.

Dewi Yanti, F. (2018). Pengaruh Profitability, Capital Intensity, Inventory Intensity, Leverage, dan Risk Management Comittee Terhadap Tax Avoidance. 1-17.

Fadrianto, I. P., \& Mulyani, S. D. (2018). Pengaruh Manajemen Risiko Dan Karakteristik Perusahaan Terhadap Penghindaran Pajak Dengan Pengungkapan Corporate Social Responsibility Sebagai $\begin{array}{lllll}\text { Variabel Moderasi. Jurnal } & \text { Ilmiah }\end{array}$ https://doi.org/10.32528/psneb.v0i0.5194.

Ghozali, I. (2017). Analisis Multivariate dan Ekonometrika: Teori, Konsep dan Aplikasi dengan 
menggunakan EViews 10. In Badan Penerbit Universitas Diponegoro.

Hajawiyah, A., Suryarini, T., Kiswanto, \& Tarmudji, T. (2021). Analysis of a tax amnesty's effectiveness in Indonesia. Journal of International Accounting, Auditing and Taxation, 44. https://doi.org/10.1016/j.intaccaudtax.2021.100415.

Han, X., Wang, J., \& Cheng, H. (2021). The effect of corporate tax avoidance on salary distribution-Empirical evidence from publicly listed companies in China. International Review of Financial Analysis, 78. https://doi.org/10.1016/j.irfa.2021.101917.

Hasan, I., Kim, I., Teng, H., \& Wu, Q. (2022). The effect of foreign institutional ownership on corporate tax avoidance: International evidence. Journal of International Accounting, Auditing and Taxation, 46. https://doi.org/10.1016/j.intaccaudtax.2021.100440.

Kovermann, J., \& Velte, P. (2019). The impact of corporate governance on corporate tax avoidance-A literature review. Journal of International Accounting, Auditing and Taxation, 36, 100270. https://doi.org/10.1016/j.intaccaudtax.2019.100270.

Lee, C.-H., \& Bose, S. (2021). Do family firms engage in less tax avoidance than non-family firms? The corporate opacity perspective. Journal of Contemporary Accounting \& Economics, 17(2). https://doi.org/10.1016/j.jcae.2021.100263.

Lestari, J., \& Solikhah, B. (2019). The Effect of CSR, Tunneling Incentive, Fiscal Loss Compensation, Debt Policy, Profitability, Firm Size to Tax Avoidance. Accounting Analysis Journal, 8(1), 31-37. https://doi.org/10.15294/aaj.v8i1.23103.

Luthan, E., Satria, I., \& Ilmainir. (2016). The Effect of Good Corporate Governance Mechanism to Earnings Management before and after IFRS Convergence. Procedia - Social and Behavioral Sciences, 219. https://doi.org/10.1016/j.sbspro.2016.05.021.

Mahanani, A., Titisari, K. H., \& Nurlaela, S. (2017). Pengaruh Karateristik Perusahaan, Sales Growth, dan CSR Terhadap Tax Avoidance. IENACO, 732-742. https://doi.org/10.21460/jrak.2018.141.294.

Najafi-Tavani, S., Sharifi, H., Naudé, P., \& Parvizi-Omran, E. (2022). The impact of alternative financial supply chain management practices on supply risk: A relationship quality and buyer relative power $\begin{array}{llll}\text { perspective. } & \text { Industrial } & \end{array}$ https://doi.org/10.1016/j.indmarman.2021.11.007.

Popp, T. R., Feindt, P. H., \& Daedlow, K. (2021). Policy feedback and lock-in effects of new agricultural policy instruments: A qualitative comparative analysis of support for financial risk management tools in OECD countries. Land Use Policy, 103. https://doi.org/10.1016/j.landusepol.2021.105313.

Portillo, J., \& Block, W. E. (2012). Negative effects of US taxation. Studies in Economics and Finance, 29(2), 76-88. https://doi.org/10.1108/10867371211229109.

Pratiwi, B. (2018). Pengaruh Pajak, Exchange Rate, Tunneling Incentive, Dan Leverage Terhadap Transfer Pricing. Jurnal Ekonomi Dan Bisnis, 19(3). https://doi.org/10.30659/ekobis.19.3.90-103.

Puspitaningrum, D., \& Atmini, S. (2012). Corporate Governance Mechanism and the Level of Internet Financial Reporting: Evidence from Indonesian Companies. Procedia Economics and Finance, 2. https://doi.org/10.1016/S2212-5671(12)00075-5.

Putri, M. (2017). Pengaruh Kompensasi Manajemen, Corporate Governance, Reputasi Auditor terhadap Manajemen Pajak (Studi Empiris pada Perusahaan Perbankan yang Terdaftar di Bei Tahun 20112014). Jurnal Online Mahasiswa Fakultas Ekonomi Universitas Riau, 4(1), 294-308.

Rani, S., Susetyo, D., \& Fuadah, L. L. (2018). The effects of the corporate's characteristics on tax avoidance moderated by earnings management (Indonesian evidence). Journal of Accounting, Finance and Auditing Studies, 4(3), 149-169. https://doi.org/10.24843/JIAB.2020.v15.i02.p10.

Rifan, D. F. (2019). Analisis Penerapan Tunneling Incentive dan Mekanisme Bonus terhadap Praktik Penghindaran Pajak. Jurnal Keuangan Dan Perbankan, 2(April 2019), 31-37. https://doi.org/10.24127/jf.v2i1.360.

Rosid, A., Evans, C., \& Tran-Nam, B. (2018). Tax Non-Compliance and Perceptions of Corruption: Policy Implications for Developing Countries. Bulletin of Indonesian Economic Studies, 54(1), 25-60. https://doi.org/10.1080/00074918.2017.1364349.

Rustinsyah, R., Prasetyo, R. A., \& Adib, M. (2021). Social capital for flood disaster management: Case study of flooding in a village of Bengawan Solo Riverbank, Tuban, East Java Province. International Journal of Disaster Risk Reduction, 52. https://doi.org/10.1016/j.ijdrr.2020.101963.

Sadewo, G. N., \& Hartiyah, S. (2017). Pengaruh Kompensasi Manajemen, Reputasi Auditor, Profitabilitas dan Leverage terhadap Manajemen Pajak pada Perusahaan Perbankan Konvensional yang Terdaftar di BEI Periode 2011 sampai 2015. Ekp, 13(3), 1576-1580.

Shams, S., Bose, S., \& Gunasekarage, A. (2022). Does corporate tax avoidance promote managerial empire building? Journal of Contemporary Accounting \& Economics, 18(1). https://doi.org/10.1016/j.jcae.2021.100293. 
Sugiyanto, S., Febrianti, F. D., \& Suripto, S. (2020). Good Corporate Governance And Tax Avoidance To Cost Of Debt With Growth Opportunityas Moderating (Empirical Study on Manufacturing Company and Finance Service Listed in IDX 2015-2019). The Accounting Journal of Binaniaga, 5(2), 123. https://doi.org/10.33062/ajb.v5i2.406.

Suripto, \& Sugiyanto. (2020). Transparansi Perusahaan Memoderasi Pengaruh Tax Avoidance Dan Leverage Terhadap Nilai Perusahaan Manufaktur Di Bursa Efek Indonesia. Proceedings Universitas Pamulang, 1(1), 1-11.

Tang, T., Xu, L., Yan, X., \& Yang, H. (2022). Simultaneous debt-equity holdings and corporate tax avoidance. Journal of Corporate Finance, 72. https://doi.org/10.1016/j.jcorpfin.2021.102154.

Tang, T. Y. H. (2016). Privatization, tunneling, and tax avoidance in Chinese SOEs. Asian Review of Accounting, 24(3), 274-294. https: //doi.org/10.1108/ARA-08-2014-0091.

Uemura, T. (2022). Evaluating Japan's Corporate Income Tax Reform using Firm-specific Effective Tax Rates. Japan and the World Economy. https://doi.org/10.1016/j.japwor.2022.101115.

Varga, S., Brynielsson, J., \& Franke, U. (2021). Cyber-threat perception and risk management in the Swedish financial sector. Computers \& Security, 105. https://doi.org/10.1016/j.cose.2021.102239.

Wardani, D. K., \& Purwaningrum, R. (2018). Pengaruh Karakteristik Perusahaan Dan Corporate Social terhadap Penghindaran Pajak. Jurnal Review AKuntansi Keuangan, 14(1), 1-11. https://doi.org/10.32528/psneb.v0i0.5194.

Yang, Q., Wang, Y., \& Ren, Y. (2019). Research on financial risk management model of internet supply chain based on data science. Cognitive Systems Research, 59. https://doi.org/10.1016/j.cogsys.2019.02.001. 